\title{
Compositional and kinetic controls on liquid immiscibility in ferrobasalt-rhyolite volcanic and plutonic series
}

\author{
Bernard Charlier $^{\mathrm{a}, *}$, Olivier Namur ${ }^{\mathrm{b}}$, Timothy L. Grove ${ }^{\mathrm{a}}$ \\ ${ }^{a}$ Department of Earth, Atmospheric and Planetary Sciences, Massachusetts Institute of Technology, Cambridge, MA 02139, USA \\ ${ }^{\mathrm{b}}$ Department of Earth Sciences, University of Cambridge, Downing Street, Cambridge CB2 3EQ, UK
}

Received 19 July 2012; accepted in revised form 11 March 2013; Available online 28 March 2013

\begin{abstract}
We present major element compositions of basalts and their differentiation products for some major tholeiitic series. The dry, low-pressure liquid lines of descent are shown to approach or intersect the experimentally-defined compositional space of silicate liquid immiscibility. Ferrobasalt-rhyolite unmixing along tholeiitic trends in both volcanic and plutonic environments is supported by worldwide occurrence of immiscible globules in the mesostasis of erupted basalts, unmixed melt inclusions in cumulus phases of major layered intrusions such as Skaergaard and Sept Iles, and oxide-rich ferrogabbros closely associated with plagiogranites in the lower oceanic crust. Liquid immiscibility is promoted by low-pressure, anhydrous fractional crystallization that drives the low $\mathrm{Al}_{2} \mathrm{O}_{3}$, high $\mathrm{FeO}$ liquids into the two-liquid field. Kinetic controls can be important in the development of two-liquid separation. The undercooling that occurs at the slow cooling rates of plutonic environments promotes early development of liquid immiscibility at higher temperature. In contrast rapid cooling in erupted lavas leads to large undercoolings and liquid immiscibility develops at significantly lower temperatures. Unmixing leads to the development of a compositional gap characterized by the absence of intermediate compositions, a feature of many tholeiitic provinces. The compositions of experimental unmixed silica-rich melts coincide with those of natural rhyolites and plagiogranites with high $\mathrm{FeO}_{\text {tot }}$ and low $\mathrm{Al}_{2} \mathrm{O}_{3}$, suggesting the potential role of large-scale separation of immiscible Si-rich liquid in the petrogenesis of late-stage residual melts. No trace of the paired ferrobasaltic melt is found in volcanic environments because of its uneruptable characteristics. Instead, $\mathrm{Fe}-\mathrm{Ti} \pm \mathrm{P}$-rich gabbros are the cumulate products of immiscible Fe-rich melts in plutonic settings. The immiscibility process may be difficult to identify because both melts crystallize the same phases with the same compositions. The two liquids might form incompletely segregated emulsions so that both liquids continue to exchange as they crystallize and remain in equilibrium. Even if segregated, both melts evolve on the binodal surface and exsolve continuously with decreasing temperature. The two liquids do not differentiate independently and keep crystallizing the same phases with differentiation. Further evolution by fractional crystallization potentially drives the bulk liquid out of the twoliquid field so that very late-stage liquids could evolve into the single melt phase stability field.
\end{abstract}

(c) 2013 Elsevier Ltd. All rights reserved.

\section{INTRODUCTION}

Detailed examination of Apollo 11 and 12 lunar rocks led to the first identification of silicate liquid immiscibility in natural samples (Roedder and Weiblen, 1970, 1971), after unmixing between iron- and silica-rich melts had been recognized experimentally (Roedder, 1951). Evidence for the sep-

\footnotetext{
* Corresponding author. Tel.: +1 617253 6398; fax: +1 617253 7102 .

E-mail address: charlier@mit.edu (B. Charlier).
}

aration of ferrobasalt and rhyolite melts has thereafter been presented in both volcanic (De, 1974; Sato, 1978; Philpotts, 1979, 1982) and plutonic environments (McBirney, 1975). Based on anhydrous low-pressure crystallization experiments, Dixon and Rutherford (1979) proposed that liquid immiscibility and segregation of the Si-rich melt may form plagiogranites from mid-ocean ridge basalts, and thus regarded this process as a potential large-scale mechanism. Even so, this model had lost support, mainly due to the absence of Fe-enriched conjugate liquid, albeit abundant oxide-rich ferrogabbro horizons have now been reported in 
Table 1

Compositional characteristics of some important ferrobasaltic provinces from different tectonic settings.

\begin{tabular}{|c|c|c|c|}
\hline & $\mathrm{SiO}_{2} / \mathrm{FeO}_{\text {tot }}$ parental magma & $\mathrm{SiO}_{2} / \mathrm{FeO}_{\text {tot }}$ at maximum $\mathrm{Fe}$-enrichment & Immiscible inclusions \\
\hline \multicolumn{4}{|c|}{ Continental flood basalts } \\
\hline Emeishan traps ${ }^{\mathrm{a}}$ & $45-47 / 10-12$ & $45 / 15$ & \multirow{7}{*}{$\begin{array}{l}* \\
*\end{array}$} \\
\hline Deccan traps ${ }^{\mathrm{b}}$ & $49-50 / 12$ & $49-50 / 16$ & \\
\hline Columbia River ${ }^{\mathrm{c}}$ & $48-50 / 10$ & $46-48 / 16-17$ & \\
\hline Madagascar $^{\mathrm{d}}$ & $45-46 / 10-11$ & $50 / 16$ & \\
\hline Parana-Etendeka $\mathrm{e}^{\mathrm{e}}$ & $50-52 / 10$ & $50 / 14-15$ & \\
\hline Yemen and & $45-46 / 10$ & $46-47 / 14-15$ & \\
\hline \multicolumn{3}{|l|}{ Ethiopia $^{\mathrm{f}}$} & \\
\hline \multicolumn{4}{|l|}{ Ocean ridges } \\
\hline Galapagos $^{\mathrm{g}}$ & $49 / 10$ & $49 / 19$ & \\
\hline Juan de Fuca ${ }^{\mathrm{h}}$ & $50 / 10$ & $50 / 16$ & \\
\hline Nynety East $\mathrm{i}^{\mathrm{i}}$ & $47 / 10$ & $48 / 15$ & \\
\hline Spiess $^{\mathrm{j}}$ & $50 / 10$ & $50 / 14$ & \\
\hline Walvis ${ }^{\mathrm{k}}$ & $48 / 11$ & $46-48 / 15$ & \\
\hline Reykjanes $^{1}$ & $49 / 10$ & $45 / 17$ & \\
\hline \multicolumn{4}{|l|}{ Continental rifting } \\
\hline Greenland $^{\mathrm{m}}$ & $48 / 10$ & $46 / 17$ & \multirow[b]{2}{*}{$*$} \\
\hline Mull volcanon $^{\mathrm{n}}$ & $48-49 / 10$ & $47 / 15-16$ & \\
\hline \multicolumn{4}{|l|}{ Ocean island } \\
\hline Iceland $^{\circ}$ & $48-49 / 9-10$ & $48-49 / 16$ & \multirow[t]{3}{*}{$*$} \\
\hline Galapagos $^{\mathrm{p}}$ & $48 / 10$ & $48-49 / 18-19$ & \\
\hline Azores $^{\mathrm{q}}$ & $48 / 12$ & $48 / 14$ & \\
\hline \multicolumn{4}{|l|}{ Oceanic plateau } \\
\hline Kerguelen $^{r}$ & $50 / 12$ & $49 / 17$ & $*$ \\
\hline
\end{tabular}

${ }^{\mathrm{a}}$ Xu et al. (2001); ${ }^{\mathrm{b}}$ Sano et al. (2001); ${ }^{\mathrm{c}}$ Hooper (2000); ${ }^{\mathrm{d}}$ Mahoney et al. (2008); ${ }^{\mathrm{e}}$ Peate et al. (1992); ${ }^{\mathrm{f}}$ Pik et al. (1998); ${ }^{\mathrm{g}}$ Byerly et al. (1976) and Fornari et al. (1983); ${ }^{\mathrm{h}}$ Smith et al. (1994); ${ }^{\mathrm{i}}$ Ludden et al. (1980); ${ }^{\mathrm{j}}$ le Roex et al. (1982); ${ }^{\mathrm{k}}$ Humphris and Thompson (1982); ${ }^{1}$ Melson and O'Hearn (1986); ${ }^{\mathrm{m}}$ Brooks and Nielsen (1978); ${ }^{\mathrm{n}}$ Kerr et al. (1999); ${ }^{\circ}$ Carmichael (1964); ${ }^{\mathrm{p}}$ Mungall and Martin (1995); ${ }^{\mathrm{q}}$ Geist et al. (1995); ${ }^{\mathrm{r}}$ Mahoney et al. (1995).

the lower oceanic crust and in ophiolite complexes (e.g. Dick et al., 1991, 2000; Montanini et al., 2006).

In this contribution, silicate liquid immiscibility is recognized as a viable differentiation process along the dry, lowpressure evolution from tholeiitic basalt to rhyolite. Immiscibility can develop as a thermodynamically stable process and is not restricted to a metastable phenomenon (Irvine, 1976; Biggar, 1979). In addition to the worldwide presence of immiscible droplets of glasses trapped in the mesostasis of basalts (e.g. De, 1974; Philpotts, 1982; Luais, 1987; Kontak et al., 2002), silicate liquid immiscibility can be identified in slowly cooled plutonic environments, such as the mafic Skaergaard, Sept Iles, Bushveld and Duluth layered intrusions where silica and iron-rich melts have segregated at mm- to m-scale (McBirney, 1975; Ripley et al., 1998; Jakobsen et al., 2005, 2011; Charlier et al., 2011; Namur et al., 2012; VanTongeren and Mathez, 2012).

We make use of available major element compositions of tholeiitic basalts and their derivative products of crystallization and show that the liquid line of descent of many tholeiitic provinces approaches or intersects the compositional space where two immiscible silicate liquids develop, as defined experimentally by Charlier and Grove (2012). The main implication of immiscibility on the evolution from basalt to rhyolite is that compositions between these two liquids are absent, a characteristic of many tholeiitic provinces (e.g. Daly, 1914; Chayes, 1963). Silica-rich rocks are commonly associated with the basaltic suites and are observed in Iceland, Deccan, Snake River Plain, Mull and many others magmatic provinces (e.g. Carmichael, 1964; Geist et al., 1995; Kerr et al., 1999). Plagiogranites also occur in the oceanic crust and ophiolite complexes (Coleman and Peterman, 1975). These rhyolites and plagiogranites are classically interpreted as residual liquids produced by protracted fractionation of the parental basic magma (e.g. Dixon-Spulber and Rutherford, 1983; Juster et al., 1989; Toplis and Carroll, 1995; Berndt et al., 2005) and as products of dehydration or hydrous partial melting of gabbroic rocks (Beard and Lofgren, 1991; Floyd et al., 1998; Koepke et al., 2004, 2007; France et al., 2010). These two processes are not exclusive and may occur in parallel with liquid immiscibility. In this discussion we describe the conditions under which silicate liquid immiscibility can develop and suggest that it should also be considered as a potential large-scale process to produce silica-rich melts during late-stage differentiation of tholeiitic systems in anhydrous and low-pressure conditions. This mechanism reconciles the obvious occurrence of immiscibility in layered intrusions with compositional trends of erupted lavas, and revives the original idea of Daly (1914) to explain the dearth of intermediate compositions. 

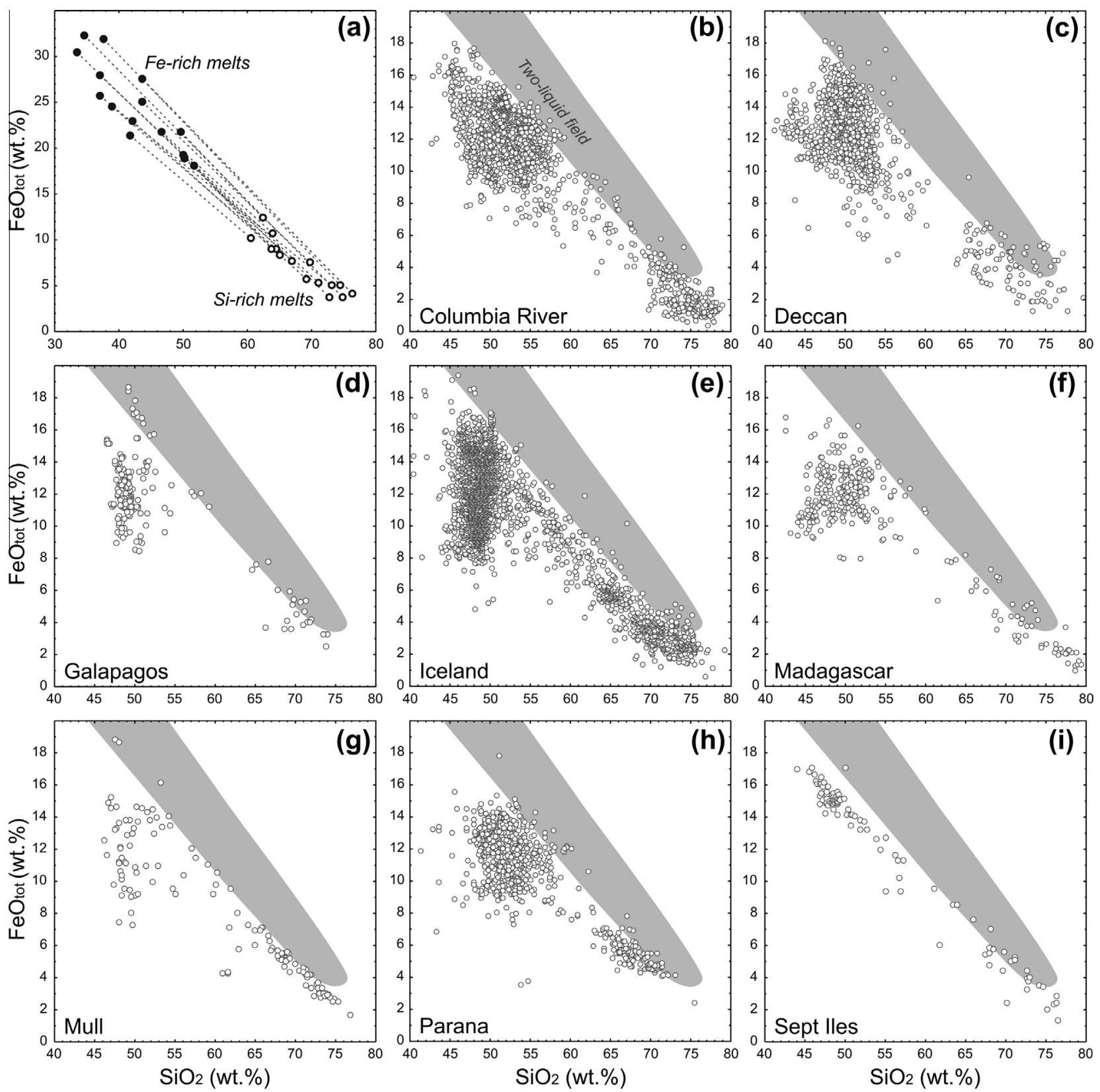

Fig. 1. (a) $\mathrm{FeO}_{\text {tot }}$ versus $\mathrm{SiO}_{2}$ diagrams for experimental immiscible melts of Charlier and Grove (2012), black circles are Fe-rich immiscible melts and white circles are Si-rich immiscible melts. Tie lines join immiscible pairs; (b-i) $\mathrm{FeO}_{\text {tot }}$ versus $\mathrm{SiO}_{2}$ for compiled lavas of some major tholeiitic provinces. Data for Columbia River, Deccan, Iceland, Madagascar, and Parana are taken from GEOROC database (http:// georoc.mpch-mainz.gwdg.de). Data for Galapagos are from Byerly et al. (1976), Byerly (1980) and Geist et al. (1995, 2006), Mull (Walsh et al., 1979; Kerr et al., 1999) and Sept Iles (Namur et al., 2011).

\section{THE RECORDS OF SILICATE LIQUID IMMISCIBILITY}

\subsection{Volcanic provinces}

Phase equilibria of tholeiitic basalts at the Earth's surface, in shallow-level magma chambers and at the mantle-crust boundary have been well studied (e.g. Walker et al., 1979; Tormey et al., 1987; Grove et al., 1992; Toplis and Carroll, 1995; Villiger et al., 2007). At surface to lowercrustal pressure, olivine and plagioclase are the first liquidus phases to crystallize which drive residual liquids on an iron enrichment and alumina depletion trend with no significant silica variation. This crystallization path ultimately leads to the formation of ferrobasalts which commonly contain more than 13-14 wt.\% FeO Fet $_{\text {(McBirney }}$ and Williams, 1969). Ferrobasalts are ubiquitous in the tectonic settings were tholeiitic basalts occur. Geochemical 
characteristics for parental magmas to some ferrobasaltic provinces and the maximum iron enrichment reached by the liquid lines of descent are presented in Table 1. These are the compositions that are spatially associated with silica-rich lavas.

We have compiled major element composition for some tholeiitic provinces (Fig. 1). The data show similar evolutions with initial iron enrichment trends from 10 to $12 \mathrm{wt} . \% \mathrm{FeO}_{\text {tot }}$ in primitive mantle-derived parental magmas to $15-18 \mathrm{wt} . \% \mathrm{FeO}_{\text {tot }}$ in ferrobasalts. The silica content during this interval remains relatively constant between 45 and $52 \mathrm{wt} . \% \mathrm{SiO}_{2}$. The trend is then marked by iron depletion and silica enrichment, which correspond to the appearance of Fe-Ti oxides on the liquidus. All the tho-

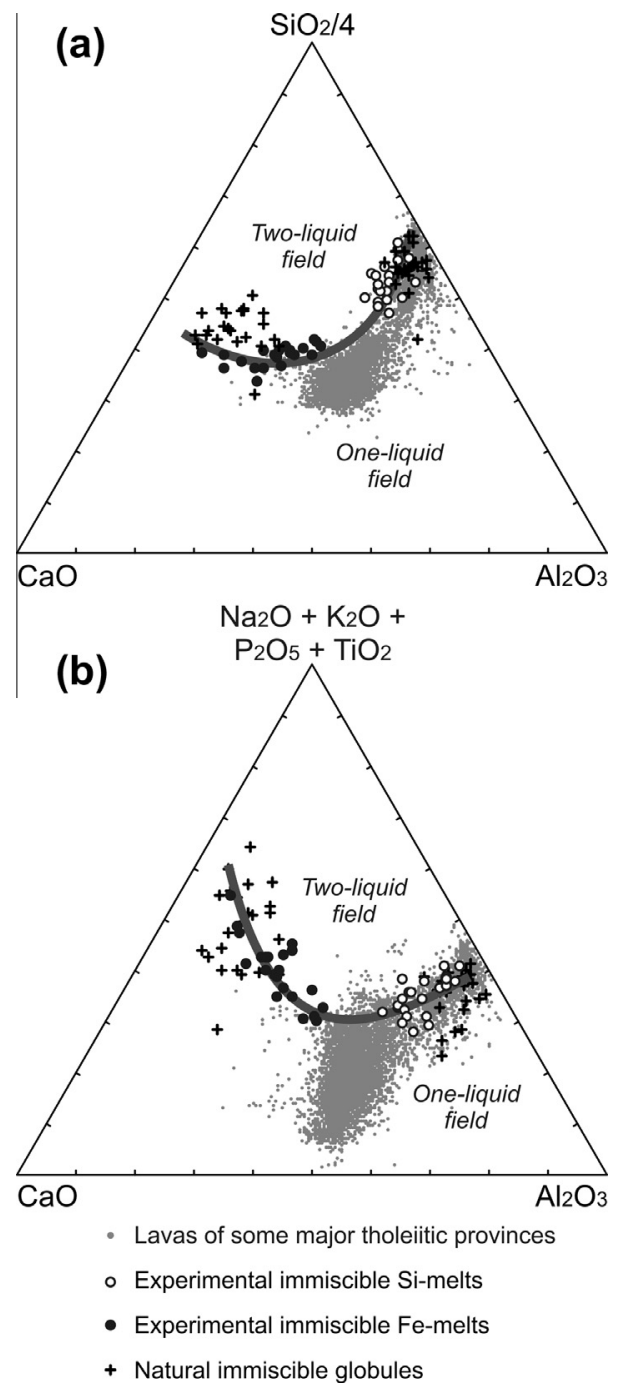

Fig. 2. Tholeiitic basalts and their products of differentiation compared to experimental and natural immiscible melts projected onto ternary diagrams with (a) $\mathrm{CaO}, \mathrm{Al}_{2} \mathrm{O}_{3}$ and $\mathrm{SiO}_{2} / 4$, and (b) $\mathrm{CaO}, \mathrm{Al}_{2} \mathrm{O}_{3}$ and $\mathrm{Na}_{2} \mathrm{O}+\mathrm{K}_{2} \mathrm{O}+\mathrm{P}_{2} \mathrm{O}_{5}+\mathrm{TiO}_{2}$. Compositions from tholeiitic provinces from the same database as the one used for Fig. 1. Experimental immiscible melts are from Charlier and Grove (2012) and natural immiscible globules are from Table 3 and from Philpotts (1982). leiitic provinces presented in Fig. 1 display an absence or dearth of intermediate compositions. This gap spans the region from $52-53$ wt. $\%$ to $60-65$ wt. $\% \mathrm{SiO}_{2}$. Moreover, some of the intermediate compositions are basalt-rhyolite hybrids and these are not produced by fractional crystallization but by mixing across the gap (e.g. Geist et al., 1995; Namur et al., 2011). Evolved compositions with silica content higher than $60-65 \mathrm{wt} . \% \mathrm{SiO}_{2}$ are contrastingly relatively abundant. In Fig. 1a we have plotted the compositions of immiscible melts obtained by Charlier and Grove (2012) during crystallization of evolved basalts representative of tholeiitic paths (Sept Iles, Mull, Iceland and Snake River Plain). These immiscible pairs define a locus where unmixing develops and homogeneous melts cannot exist. This two-liquid stability field is represented by a grey area and compared to compositions in tholeiitic provinces (Fig. 1). Compositions from tholeiitic provinces are also projected onto ternary diagrams (Fig. 2) together with experimental immiscible melts that define the location of the binodal curve. The curve marks the limit between the one-liquid and the two-liquid fields. These figures show that very few compositions found in volcanic environments might be representative of immiscible ferrobasaltic melts. However, the compositional space for experimental silicic immiscible melts is hardly distinguishable from that of natural silicic melts, although immiscible melts are mostly located on the low $-\mathrm{Al}_{2} \mathrm{O}_{3}$ side of natural compositions. It is also notable that very few data from tholeiitic provinces plot in this stability field for coexisting immiscible liquids.

Following the first identification of immiscible melts in interstitial glasses of basalts (Roedder and Weiblen, 1971; De, 1974), the seminal study of Philpotts (1982) presented evidence for unmixing in most tholeiitic provinces. Some provinces in which immiscibility has been identified are reported in Table 1. Immiscible textures developed in the mesostasis of basalts consist of brown spheres, usually smaller than $10 \mu \mathrm{m}$, enclosed in a clear silica-rich glass (Fig. 3). Dark globules are usually finely crystallized to $\mathrm{Fe}-\mathrm{Ti}$ oxides, iron-rich pyroxene and other fine-grained material. The Si-rich melt is more abundant than Fe-globules, supporting that immiscibility was reached after significant silica enrichment and iron depletion of the bulk interstitial liquid. Similar textures have been recognized by other authors (e.g. Kontak et al., 2002) and immiscible thin fine-grained rhyolite bands have even been shown to have segregated from differentiated layers of lavas (Greenough and Dostal, 1992).

\subsection{Plutonic environments}

Ferrobasalts are the parental magmas to some of the most intensively studied shallow mafic layered intrusions (Table 2), such as Skaergaard, Greenland (Wager and Brown, 1968; Hoover, 1989; Jakobsen et al., 2010), the Upper and Main Zones of the Bushveld complex, South Africa (Tegner et al., 2006; VanTongeren et al., 2010) and Sept Iles, Canada (Namur et al., 2010, 2011). In plutonic settings, the ferrobasaltic liquid line of descent is difficult to decipher due to the scarcity of samples fully-representative of liquid compositions. This issue was mainly investi- 

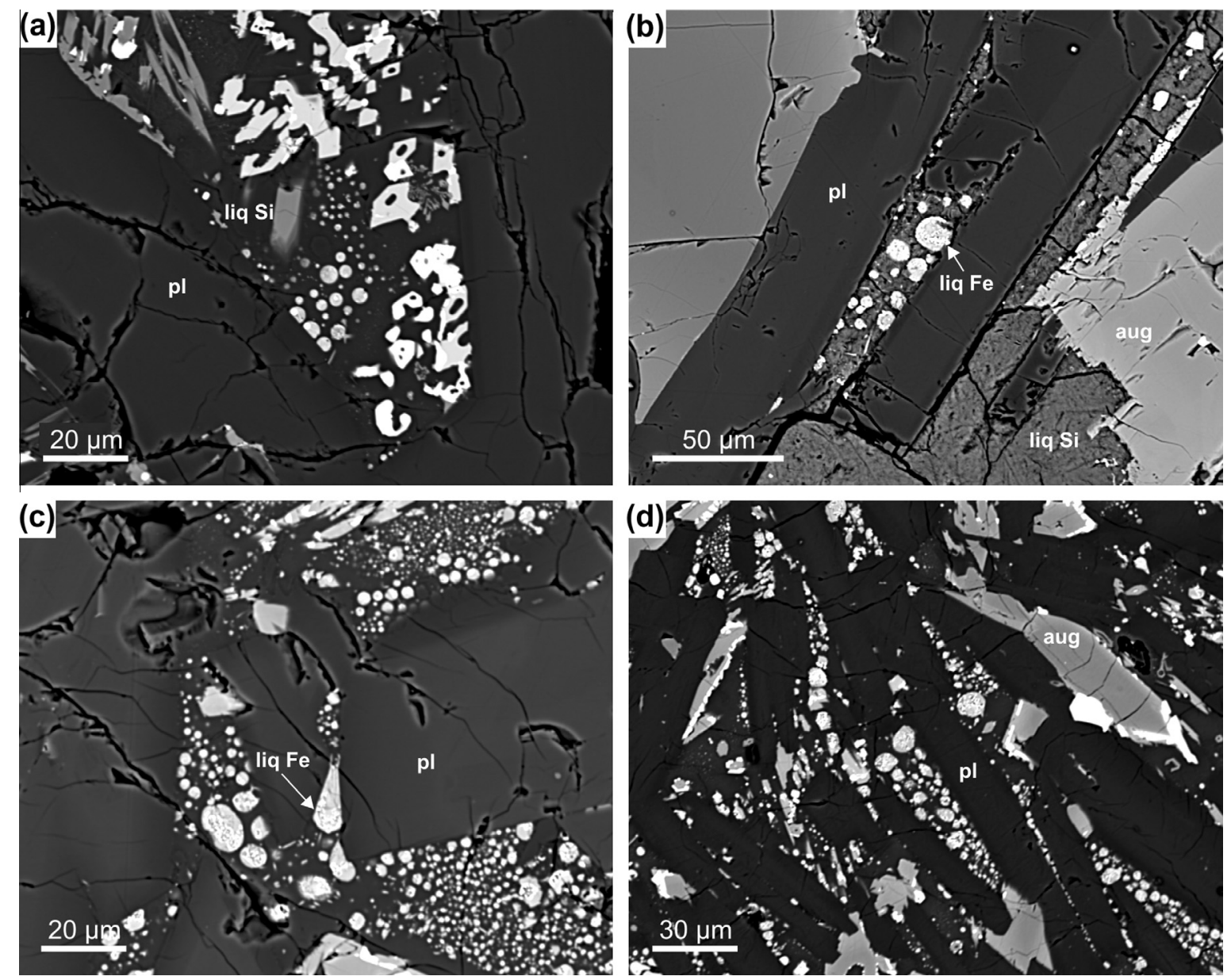

Fig. 3. Back-scattered electron images of immiscible textures in volcanic rocks from some famous tholeiitic provinces. (a) McKinney basalt, Snake River Plain, Malad river at junction with Snake River, Idaho (sample 66,162); (b) Olivine basalt from Blowsa quarry, Tansa, Bombay, Deccan traps (sample 27,090); (c) Basalt from Jokulsa a Fjöllum, Iceland (sample 83,496); (d) Andesite from the 1845 lava of Hekla volcano, Iceland (sample 20,506). Sample name refers to number in the Harker collection, University of Cambridge. liq Si, silica-rich immiscible liquid; liq $\mathrm{Fe}$, iron-rich immiscible liquid; $p l$, plagioclase and aug, augite.

Table 2

Characteristics of some ferrobasaltic layered intrusions.

\begin{tabular}{llll}
\hline & $\begin{array}{l}\text { Parent magma } \\
\mathrm{SiO}_{2} / \mathrm{FeO}_{\text {tot }}\end{array}$ & Silicic liquid & Immiscibility \\
\cline { 2 - 4 } Bushveld, South Africa $^{\mathrm{a}}$ & $49 / 11-12$ & Granite & $*$ \\
Sept Iles, Canada $^{\mathrm{b}}$ & $48 / 15$ & Granite & $*$ \\
Duluth, USA $^{\mathrm{c}}$ & $48 / 11-15$ & Granophyre & $*$ \\
Bjerkreim-Sokndal, Norway $^{\mathrm{d}}$ & $50 / 13$ & Charnockite & $*$ \\
McIntosh, Australia $^{\mathrm{e}}$ & $48 / 14$ & Granite & Granite \\
Newark-Island, Canada $^{\mathrm{f}}$ & $47 / 15$ & Granophyre & $*$ \\
Skaergaard, Greenland $^{\mathrm{g}}$ & $48 / 12-14$ & - &
\end{tabular}

\footnotetext{
${ }^{\mathrm{a}}$ Upper and Main zones: Tegner et al. (2006) and VanTongeren et al. (2010); ${ }^{\mathrm{b}}$ Namur et al. (2010); ${ }^{\mathrm{c}}$ Miller and Ripley (1996); ${ }^{\mathrm{d}}$ Wilson et al. (1996); ${ }^{\mathrm{e}}$ Mathison and Hamlyn (1987); ${ }^{\mathrm{f}}$ Wiebe and Snyder (1993); ${ }^{\mathrm{g}}$ See Fig. 4 for references; ${ }^{\mathrm{h}}$ Duchesne et al. (2006).
}

gated for the Skaergaard intrusion on the basis of experimental liquid compositions (Toplis and Carroll, 1995; Thy et al., 2006), mass-balance calculations between parental basalt and cumulate-rock compositions (Hunter and Sparks, 1987; Toplis and Carroll, 1996; Thy et al., 2009), and using plagioclase iron content as a proxy for equilibrium melt composition (Tegner, 1997; Tegner and Cawthorn, 2010). All these approaches support the notion that fractional crystallization of plagioclase and olivine \pm clinopyroxene during the first stages of ferrobasaltic 


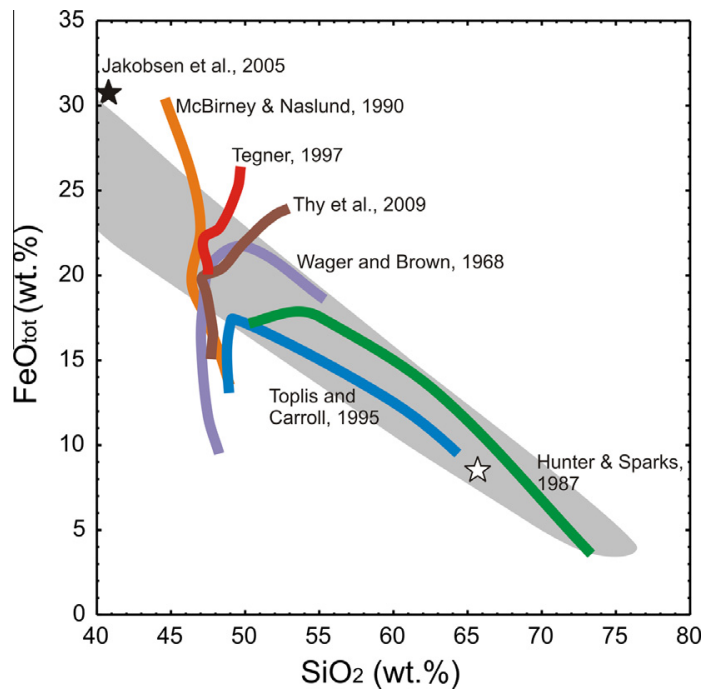

Fig. 4. $\mathrm{FeO}_{\text {tot }}$ versus $\mathrm{SiO}_{2}$ diagram showing proposed liquid lines of descent for the Skaergaard layered intrusion. Stars represent the average composition of immiscible Fe- and Si-rich melt inclusions found in cumulus apatite by Jakobsen et al. (2005).

differentiation results in iron enrichment, whereas the liquid silica content is constant or slightly decreasing (Fig. 4). In contrast, for $\mathrm{Fe}-\mathrm{Ti}$ oxide-saturated melts, two different hypotheses are commonly proposed: (1) residual liquids evolve toward $\mathrm{FeO}$ depletion and $\mathrm{SiO}_{2}$ enrichment (Wager and Brown, 1968; Hunter and Sparks, 1987; Toplis and Carroll, 1996), or (2) residual liquids are continuously enriched in $\mathrm{FeO}$, and the liquid $\mathrm{SiO}_{2}$ content may slightly decrease or increase (McBirney and Naslund, 1990; Tegner, 1997; Thy et al., 2009). The liquid lines of descent calculated for the Skaergaard layered intrusion passed through the compositional field in which immiscibility develops (Fig. 4). Iron enrichment trends even display $\mathrm{FeO}_{\text {tot }}$ concentrations higher than $25 \mathrm{wt} . \%$. This inconsistency for calculated compositional evolution trends can be explained if immiscibility is considered.

In plutonic environments, immiscibility was first described in the Skaergaard intrusion (McBirney, 1975) where meter-scale segregations of ferrogabbros were identified. Nevertheless, the overall effect of immiscibility on magmatic differentiation processes and the Skaergaard liquid line of descent remained unclear. Further studies however support that the Middle Zone and more evolved cumulates of the intrusion have crystallized from an emulsion of immiscible iron- and silica-rich liquids (Holness et al., 2011; Humphreys, 2011; Jakobsen et al., 2011) rather than from two fully segregated immiscible liquids. This is shown by wide compositional ranges of liquid trapped as melt inclusions in apatite and plagioclase (Jakobsen et al., 2011). In the Sept Iles layered intrusion, the two liquids have segregated and produced two types of cumulates alternating vertically at a scale of 5-25 m: low-density plagioclase-rich cumulates and high-density $\mathrm{Fe}-\mathrm{Ti}$ oxides and apatite-rich cumulates (Charlier et al., 2011; Namur et al., 2012). The two types of cumulate display the same cumulus assemblages, with similar phase compositions but different proportions. Immiscibility is also reported in the Duluth layered intrusion (Ripley et al., 1998) and at the top of the Bushveld complex (VanTongeren and Mathez, 2012).

Immiscibility has also often been mentioned to develop in Proterozoic anorthosites suites, the products of lower crustal tholeiitic differentiation (Frost and Frost, 1997; Vander Auwera et al., 1998). In the Bjerkreim-Sokndal layered intrusion, Wilson and Overgaard (2005) invoke the potential role of unmixing at the transition between the Layered Series and the overlying silicic evolved rocks. The late stage differentiation of an anorthositic pluton of the Nain complex was also controlled mainly by liquid immiscibility that produced iron- and silica-rich liquids (Wiebe, 1979). Experiments have shown that mixtures of jotunite and quartz mangerite, the most common melt compositions associated with anorthosites, are indeed immiscible (Philpotts, 1981).

In the gabbroic lower oceanic crust, the main potential occurrence of immiscibly has been described in the ultraslow-spreading SW Indian Ridge (Dick et al., 2000).
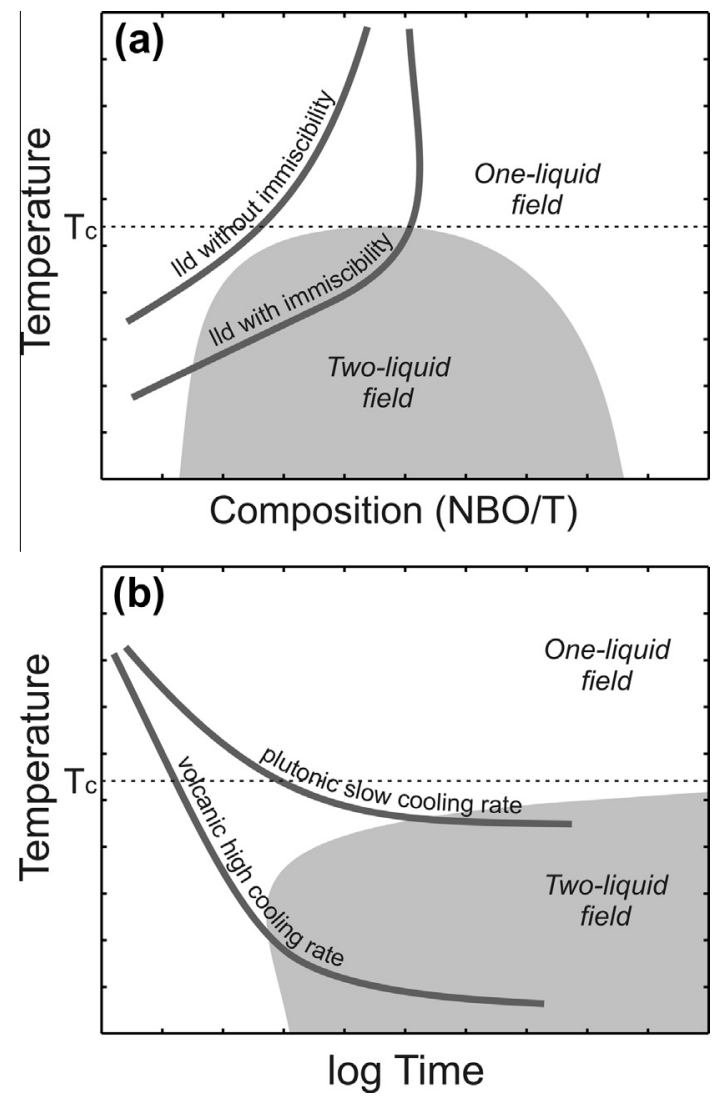

Fig. 5. Schematic illustrations for the potential development of immiscibility along tholeiitic liquid lines of descent. (a) Evolution of two liquid lines of descent (lld) in a temperature-composition (e.g. NBO/T) space passing outside and through a two-liquid field. $T_{\mathrm{c}}$ is the critical point for liquid immiscibility. Below this temperature two-liquids are stable. (b) Evolution of temperature as a function of time for lld under various cooling conditions. Immiscibility develops at high temperature under plutonic slow cooling rate and at lower temperature under volcanic high cooling rate. 
Oxide-rich gabbronorites, with $6-9$ wt. $\% \mathrm{TiO}_{2}$ and $\mathrm{Cr}$ content below the detection limit testifying their evolved character, have been drilled over 50-80 m (Dick et al., 1991). These rocks contain abundant ilmenite and magnetite, olivine $\left(\mathrm{Fo}_{30-50}\right)$, clinopyroxene $(\mathrm{Mg}$-number $55-65)$ and plagioclase $\left(\mathrm{An}_{30-40}\right.$; Ozawa et al., 1991). These liquidus assemblages and mineral compositions are similar to those observed in stratigraphic intervals where immiscibility has been reported in the Sept Iles layered intrusion (Charlier et al., 2011). Moreover, some silicic rocks are intimately associated with oxide-rich gabbronorites, many of the latter being cored with silicic veinlets (Natland and Dick, 2001). Intermediate liquid compositions are lacking and the liquid line of descent has been calculated to follow iron enrichment leading to immiscibility, further supported by similar phase compositions in oxide-rich gabbronorites and associated trondhjemites (Natland et al., 1991).

\section{CONDITIONS FOR IMMISCIBILITY DEVELOPMENT}

We have described some evidence for the development of immiscibility along tholeiitic trends. However, we do not propose that immiscibility is reached along all tholeiitic liquid lines of descent. Silicic compositions can be produced above the temperature of the binodal so that the crystallization path never enters the two-liquid field (Fig. 5a). This has been illustrated by several experimental studies under equilibrium conditions (e.g. Juster et al., 1989; Toplis and Carroll, 1995) that show that the liquid line of descent do not

Table 3

Composition of natural immiscible pairs and associated plagioclase and clinopyroxene.

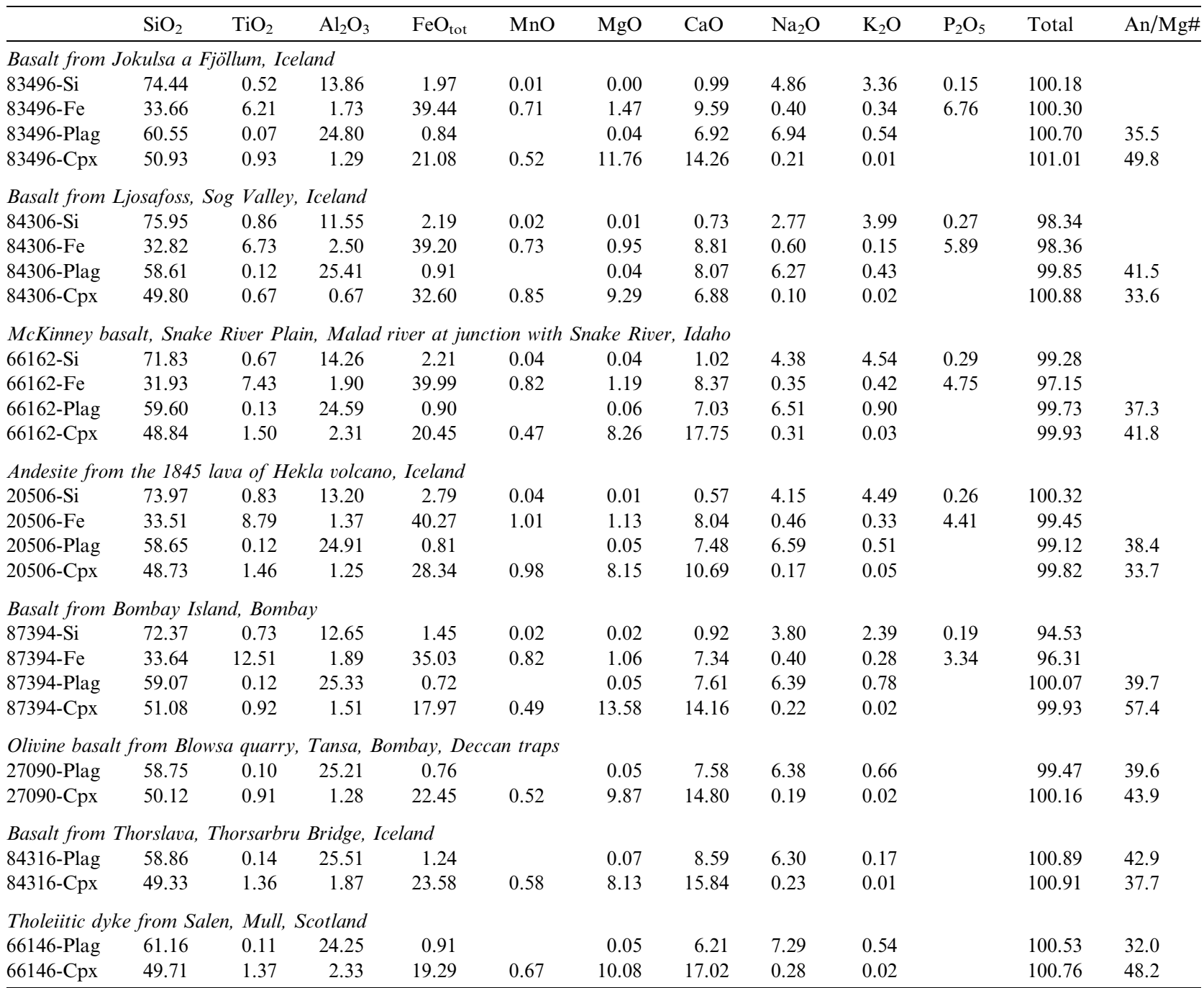

Compositions of the minerals and glasses were analyzed using the JEOL 8200 electron microprobe at MIT. Natural and synthetic primary and secondary standards were used, and the CITZAF online data correction package was used for all analyses (Armstrong, 1995). Mineral analyses were performed with a $15 \mathrm{kV}$ accelerating voltage and a beam current of $10 \mathrm{nA}$, utilizing a focused beam spot. Glass compositions were measured using a $10 \mu \mathrm{m}$ defocused beam, $10 \mathrm{nA}$ beam current, and $15 \mathrm{kV}$ accelerating voltage. Immiscible globules in samples 27090 , 84316 , and 66146 were too small to be measured with the microprobe. 
intersect the two-liquid field. Differentiation conditions, particularly pressure and water content, can also lead the evolution trend far from the compositional range of the two-liquid field, particularly by promoting iron depletion and alumina enrichment (e.g. Grove and Baker, 1984; Sisson and Grove, 1993; Villiger et al., 2007; Botcharnikov et al., 2008). The onset of immiscibility thus requires specific composition-temperature paths that are reached under specifc conditions (Charlier and Grove, 2012). Although anhydrous low-pressure fractional crystallization promotes immiscibility, it is not a sufficient condition to reach it.

The evolution of temperature as a function of time (the cooling rate) is also important for the onset of immiscibility. The time-temperature-transformation diagram (Fig 5b; Putnis and McConnell, 1980) illustrates that under slow cooling prevailing in plutonic environment, immiscibility can develop at high temperature. In erupted lavas, large undercoolings due to high cooling rates leads the evolution trend to reach the two-liquid field at lower temperature.

\section{ONSET OF LIQUID IMMISCIBILITY}

Experiments on tholeiitic basalts run in one-atmosphere furnaces under static conditions reach silicate liquid immiscibility at ca. $1020-1000{ }^{\circ} \mathrm{C}$ (Dixon and Rutherford, 1979; Philpotts, 1979; Philpotts and Doyle, 1983; Charlier and Grove, 2012). Although the onset of immiscibility is restricted to this $1020-1000{ }^{\circ} \mathrm{C}$ interval, homogeneous melts just before the onset of immiscibility exhibit a large compositional range and the first immiscible melts can be
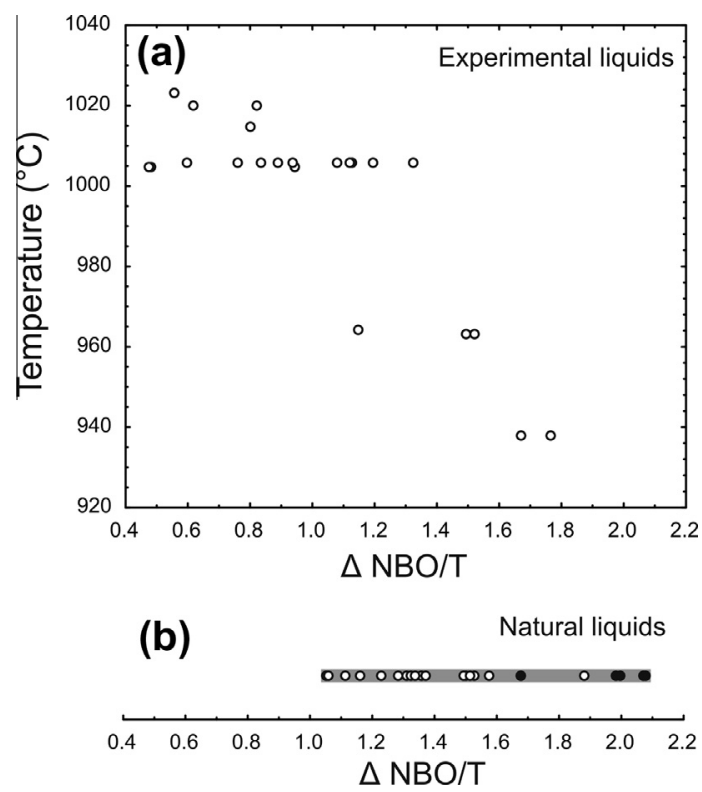

Fig. 6. Compositional differences between immiscible pairs; (a) Experimental melts obtained by Charlier and Grove (2012) and Dixon and Rutherford (1979) plotted in binary diagram with equilibrium temperature $\left({ }^{\circ} \mathrm{C}\right)$ versus the difference between the degree of polymerization of the iron-rich and the silica-rich melts $(\triangle \mathrm{NBO} / \mathrm{T})$; (b) natural immiscible pairs are from this study (black circles) and from Philpotts (1982; white circles). NBO/T calculated assuming $\mathrm{T}=\mathrm{Si}+\mathrm{Al}+\mathrm{P}+\mathrm{Ti}$ (Mysen, 1983). in equilibrium with different liquidus phases. Charlier and Grove (2012) have shown that different bulk compositions crystallizing different phase assemblages can approach the two-liquid field either along a compositional evolution trend to iron enrichment and silica depletion or one that follows silica enrichment and iron depletion. Dixon and Rutherford (1979) and Philpotts (1979) found immiscible liquids coexisting with plagioclase + clinopyroxene + ilmenite \pm magnetite. Charlier and Grove (2012) report immiscible melts in equilibrium with assemblages containing plagioclase + olivine + augite + pigeonite + ilmenite + magnetite, $\quad$ plagioclase + olivine + pigeonite + ilmenite + magnetite, plagioclase + augite + ilmenite + quartz, and plagioclase + olivine + ilmenite. The latter melts are also all saturated with whitlockite, which would be expected to be replaced by apatite in the slightly hydrous natural conditions. In these experiments, the composition of plagioclase and olivine at the onset of immiscibility covers large ranges from $\mathrm{An}_{60.4}$ to $\mathrm{An}_{36.7}$, and from $\mathrm{Fo}_{43.2}$ to $\mathrm{Fo}_{33.6}$, respectively.

The composition of immiscible droplets in lavas is also informative on the onset of immiscibility in volcanic systems. We have measured major elements of natural immiscible pairs in basalts from Iceland, Snake River Plain and Deccan (Table 3). Compared to immiscible melts obtained experimentally, the two natural immiscible liquids display highly contrasted compositions (Fig. 6) and both liquids have very low $\mathrm{MgO}$ contents (see also Philpotts, 1982). This is typical for low-temperature equilibration, when the two-liquid field is wider (Charlier and Grove, 2012). In volcanic systems,

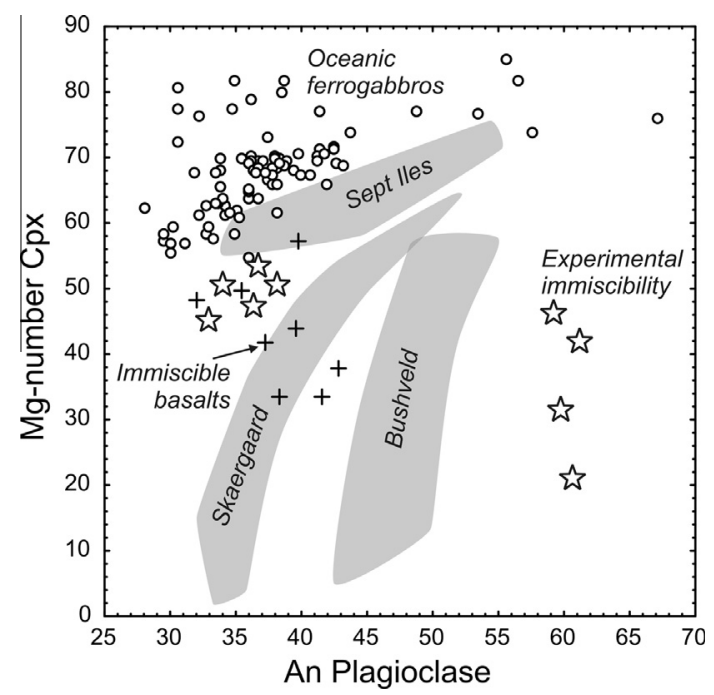

Fig. 7. Covariation between the Mg-number of clinopyroxene and the anorthite content in plagioclase in products affected or supposed to be affected by silicate liquid immiscibility. Experimental immiscible products (stars) are from Charlier and Grove (2012); immiscible basalts (crosses) are from Table 3; data are plotted for Fe-Ti-P-rich gabbros crystallized from immiscible melts in the Skaergaard (McBirney, 1989), Sept Iles (Charlier et al., 2011) and Bushveld (Tegner et al., 2006) layered intrusions; data for oceanic ferrogabbros are from hole $735 \mathrm{~B}$ in the ultra-slow-spreading SW Indian Ridge (Dick et al. 1991; Natland et al., 1991; Niu et al., 2002). 
cooling is fast and immiscibility is reached at a lower temperature compared to slow cooling systems due to kinetic effects (Fig. 5b). Moreover, the two glasses can depart from the equilibrium conjugate liquid compositional trends because each liquid is affected by rapid fractional crystallization during growth of the groundmass mineral assemblage. Fig. 2 shows that the composition of natural immiscible droplets are scattered compared to experimental melts and often plot in the two-liquid field. Fe-rich droplets might have crystallized too much pyroxene and $\mathrm{Fe}-\mathrm{Ti}$ oxide, and therefore moved towards the $\mathrm{SiO}_{2}$ apex, while Si-rich glasses did not crystallize enough plagioclase, and are higher in $\mathrm{Al}_{2} \mathrm{O}_{3}$ compared to equilibrated experimental liquids.

The compositions of minerals adjacent to immiscible droplets, especially plagioclase and pyroxene, can also be used as a probe for the onset of immiscibility, because they develop compositional zoning profiles that track the evolution of the residual melt. We have measured the compositions of plagioclase and clinopyroxene rims in contact with immiscible melts. These rims display significant thickness and are considered to be in equilibrium with trapped melt pockets in which immiscibility developed. Selected samples are from various localities: Iceland, Snake River Plain, Deccan and Mull. Plagioclase ranges from $\mathrm{An}_{43}$ to $\mathrm{An}_{32}$, the Mg-number of clinopyroxene varies from 57 to 34 (Fig. 7; Table 3). This compositional variability matches the one obtained in experiments where immiscibility develops (Charlier and Grove, 2012).

In layered intrusions, immiscibility has usually been considered to appear at the saturation of apatite (e.g. McBirney, 1975). In Sept Iles, apatite saturates at $\mathrm{An}_{52}$ and $\mathrm{Fo}_{60}$ (MCU II; Charlier et al., 2011), while apatite saturation in the Skaergaard occurred in a liquid that crystallized plagioclase $\mathrm{An}_{38-44}$ and olivine $\mathrm{Fo}_{27-32}$ (McBirney, 1989). However, Jakobsen et al. (2011) describe emulsions of immiscible silicate liquids trapped in plagioclase before the crystallization of apatite. These melt inclusions appear as soon as the Lower Zone c, when plagioclase is $\mathrm{An}_{54}$, olivine $\mathrm{FO}_{50}$ and the $\mathrm{Mg}$ number of clinopyroxene is 64 (McBirney, 1989). In the Bushveld complex, apatite saturates when $\mathrm{An}_{49}$ plagioclase and $\mathrm{Fo}_{34}$ olivine are co-crystallizing (Tegner et al., 2006), which is supposed to correspond to the onset of immiscibility (VanTongeren and Mathez, 2012). The compositions of cumulus phases at the onset of immiscibility in layered intrusions (Fig. 7) are thus more primitive compared to assemblages in basalts and in experiments. This might support the proposal of Veksler et al. $(2007,2008)$ that immiscibility could develop at higher temperature in more primitive melts. Indeed, as shown in Fig. 5b, the segregation of immiscible melts occur at higher temperature in slowly cooling magma chambers, in which appropriate conditions for decomposition and formation of two melts are met. Further growth of globules by coalescence is also favored by slow cooling conditions (Martin and Kushiro, 1991). At high temperature, close to the closure of the binodal, immiscible melts would display small compositional contrasts, so that very low interfacial tension promotes easy nucleation of immiscible liquid droplets and very slow coarsening (Veksler et al., 2010), requiring extensive period of time to enable the segregation of two liquids.
We have also compiled data from oceanic ferrogabbros from hole $735 \mathrm{~B}$ in the ultra-slow-spreading SW Indian Ridge for which the compositions of cumulus phases are available (Fig. 7; Dick et al. 1991; Natland et al., 1991; Niu et al., 2002). Natland et al. (1991) invoked immiscibility to link the origin of Fe-Ti-rich gabbros with silicic veinlets while Niu et al. (2002) suggest that simple fractional crystallization might well be adequate. Although Fig. 7 shows that for similar anorthite contents in plagioclase, the $\mathrm{Mg}$-number of clinopyroxene is higher compared to covariations for these phases in layered intrusion, the compositional ranges in hole $735 \mathrm{~B}$ is very close to that measured in the Sept Iles intrusion where immiscibility developed. This comparison supports potential unmixing during evolution of evolved basalts in oceanic settings.

\section{THE DEARTH OF INTERMEDIATE COMPOSITIONS}

Simple fractional crystallization does not explain the bimodal distribution of basalt and rhyolite observed in most volcanic provinces on Earth, including those where ferrobasalts erupt (e.g. Daly, 1914; Chayes, 1963; Thompson, 1972; Fig. 1). The dearth of intermediate liquid compositions, generally referred to as the Daly Gap, was initially attributed to a phenomenon of silicate liquid immiscibility by Daly himself. This explanation has continually lost support through time because of the absence of firm geological evidence for large-scale separation of the two immiscible liquids (Bowen, 1928). The Daly Gap observed in volcanic rocks thus came to be understood as resulting from (1) liquid density-viscosity barriers that prevent eruption of intermediate liquid compositions (Marsh, 1981; Mungall and Martin, 1995); (2) critical crystallinity that only enables crystal-liquid separation for narrow ranges of liquid compositions (Brophy, 1991; Dufek and Bachmann, 2010); (3) rapid evolution of liquid compositions at intermediate silica contents, which only produces low volumes of monzonitic melts (Grove and Donnelly-Nolan, 1986; Peccerillo et al., 2003). The production of silicic rocks by hydrous partial melting of gabbroic rocks also produced a gap for intermediate compositions between the basaltic sources and silicic partial melts (Gunnarsson et al., 1998; Koepke et al., 2004, 2007; France et al., 2010).

In this study, we show that silicate liquid immiscibility can develop along the liquid line of descent of many tholeiitic provinces. The proportion of silica-rich melt dominates that of iron-rich melt in the mesostasis of basalts, implying that immiscibility occurs after silica enrichment of the liquid line of descent. When the evolution trend reaches ca. $52-55 \mathrm{wt} . \% \mathrm{SiO}_{2}$, the production of two contrasting liquids, one with $60-75 \mathrm{wt} . \% \mathrm{SiO}_{2}$ and $4-12 \mathrm{wt} . \%$ $\mathrm{FeO}_{\text {tot }}$, the other with $30-50 \mathrm{wt} . \% \mathrm{SiO}_{2}$ and $18-32 \mathrm{wt} . \%$ $\mathrm{FeO}_{\text {tot }}$ (Charlier and Grove, 2012), is responsible for the gap in intermediate homogeneous melts. Fig. 1a illustrates that no immiscible melts occur in the 52-60 wt.\% $\mathrm{SiO}_{2}$ interval, in accordance with the gap in natural samples. 

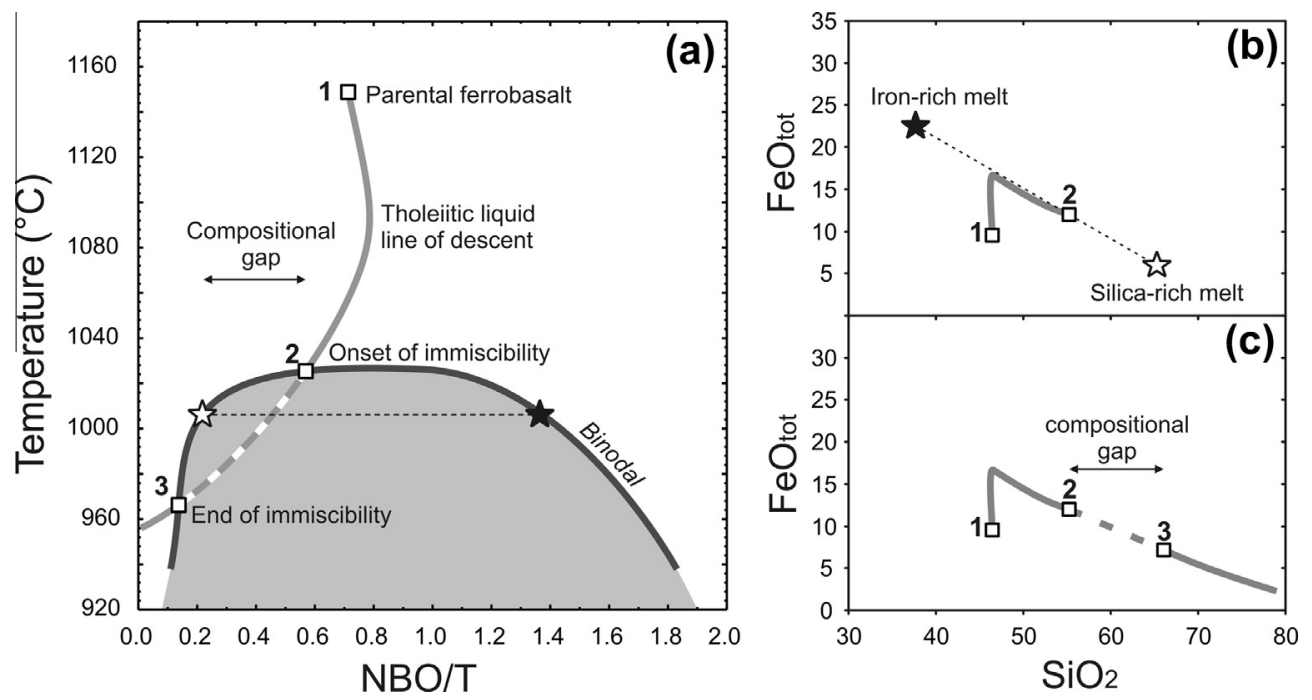

Fig. 8. Schematic models for tholeiitic liquid lines of descent reaching immiscibility with decreasing temperature. (a) Temperature as a function of the degree of polymerization $(\mathrm{NBO} / \mathrm{T})$ of melts along a tholeitic crystallization path. The shape of the binodal curve is the one obtain experimentally on the Sept Iles composition by Charlier and Grove (2012). Because of the flat shape of the binodal closure around $1020^{\circ} \mathrm{C}$, immiscibility produces a compositional gap. During the immiscibility interval, the bulk liquid line of descent (dashed line) follows silica enrichment, eventually driving the liquid out of the immiscibility field (square 3); (b) $\mathrm{FeO}_{\text {tot }}$ versus $\mathrm{SiO}_{2}$ diagram for the first stage of tholeiitic differentiation until the onset of immiscibility; (c) $\mathrm{FeO}_{\text {tot }}$ versus $\mathrm{SiO}_{2}$ diagram for the complete crystallization path with a compositional gap for intermediate compositions. Black stars are Fe-rich immiscible melts and white stars are Si-rich immiscible melts.

\section{A MODEL FOR THOLEIITIC LIQUID LINES OF DESCENT}

If a tholeiitic liquid line of descent reaches the two-liquid field during differentiation, the classical continuous evolution from basalt to rhyolite does not occur. In Fig. 8, we illustrate the evolution trend of a tholeiitic liquid of descent that reaches a binodal surface. At the onset of immiscibility, two liquids are produced. With cooling, these two equilibrium melts crystallize the same phases, with the same compositions but in different proportions. From what has been presently observed in layered intrusions (Charlier et al., 2011; Jakobsen et al., 2011), the two liquids do not seem to segregate completely from each other so that chemical exchange continues with cooling, keeping the two liquids in equilibrium. Even if separated, the two liquids would evolve on their side of the binodal curves and would exsolve the paired equilibrium melt. The two immiscible liquids do not follow independent liquid lines of descent.

With cooling, fractional crystallization drives the bulk melt composition (silica-rich + iron-rich melts) toward silica enrichment. The width of the binodal also enlarges with decreasing temperature so that the immiscible melts become more and more compositionally distinct. Fractional crystallization might lead the bulk composition to move out of the two-liquid compositional field so that the most silica-rich compositions continue evolving as a single melt-phase.

This model for tholeiitic liquid line of descent is able to explain the apparent inconsistency for calculated melt evolutions in the Skaergaard intrusion that cross the two-liquid field (Fig. 4). Mass-balance calculations using subtraction of cumulates to the parental magma give the trends of the bulk liquids without taking into account the onset of immiscibility. Calculated intermediate melts do not actually exist but represent the bulk composition of the paired silicaand iron-rich melts. The experimental liquid line of descent obtained by Toplis and Carroll (1995) represents the evolution under equilibrium conditions while the path followed during fractional crystallization, as detailed by Charlier and Grove (2012), moves into the temperature-composition space where two liquids become stable (Fig. 5).

\section{MID-OCEAN RIDGE VERSUS CONTINENTAL THOLEIITES}

Although tholeiitic basalts from various tectonic settings display similar compositional variations for major elements, systematic differences are observed between ocean and continental basalts for some minor and trace elements (Pearce et al., 1975; Meschede, 1986). This is particularly important for the development of immiscibility as potassium, titanium and phosphorous, elements that promote immiscibility (Charlier and Grove, 2012), are lower in mid-ocean ridges basalts (e.g. Pearce et al., 1975; Mullen, 1983). However, when comparing silicic melts in continental setting to plagiogranites from mid-ocean ridges and ophiolites (see Supplementary Fig. S1), it is obvious that late-stage products of basaltic evolution in these two environments do have similar characteristics for important compositional criteria relevant for silicate liquid immiscibility, i.e. $\mathrm{Al}_{2} \mathrm{O}_{3}$, the difference between alkali $\left(\mathrm{Na}_{2} \mathrm{O}+\mathrm{K}_{2} \mathrm{O}\right)$ and $\mathrm{CaO}$ and the $\mathrm{Fe}$-number. Consequently, immiscibility can develop in both environments.

\section{COMPOSITION OF IMMISCIBLE SILICA MELTS}

Whether large-scale segregation and potentially eruption of the silica-rich immiscible can occur has yet to be proven. 


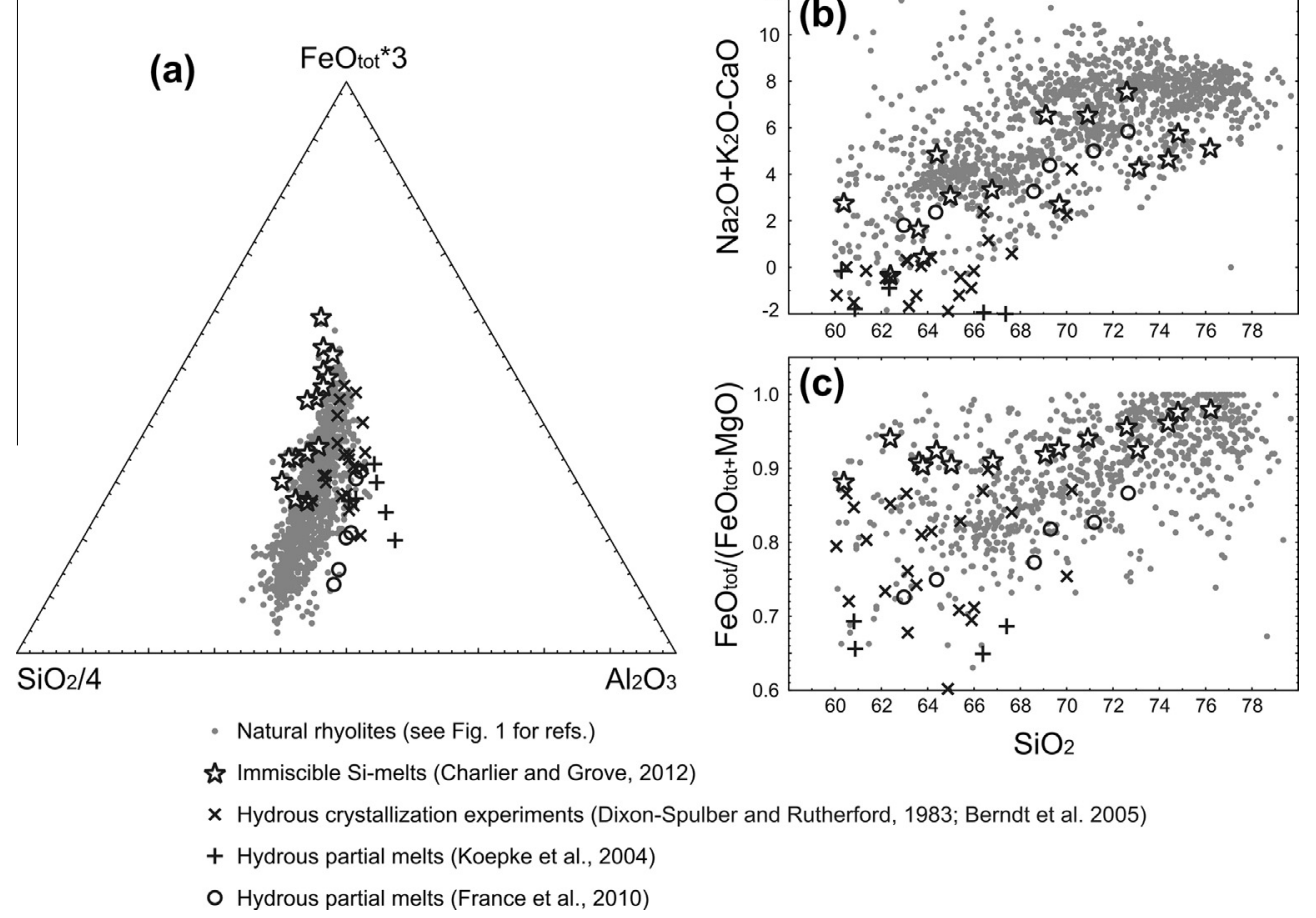

Fig. 9. Comparisons between experimentally-produced silica-rich melts and rhyolites in continental settings. (a) $\mathrm{SiO}_{2} / 4-\mathrm{FeO}_{\text {tot }}{ }^{*} 3-\mathrm{Al}_{2} \mathrm{O}_{3}$ (wt.\%); (b) $\mathrm{Na}_{2} \mathrm{O}+\mathrm{K}_{2} \mathrm{O}-\mathrm{CaO}$ versus $\mathrm{SiO}_{2}$ (wt.\%); (c) $\mathrm{FeO}_{\text {tot }} /\left(\mathrm{FeO}_{\text {tot }}+\mathrm{MgO}\right.$ ) versus $\mathrm{SiO}_{2}$ (wt.\%). Compositions filtered $>60$ wt.\% $\mathrm{SiO}_{2}$.

Rhyolites from tholeiitic provinces have ferroan alkali-calcic characteristics, following the geochemical classification for granitic rocks proposed by Frost et al. (2001). These lavas are compositionally similar to A-type granites (Bonin, 2007; Turner and Rushmer, 2009). From a compositional perspective, immiscible silicic melts have close affinities with silicic magmas observed in tholeiitic series, as shown in Fig. 9 which compares Si-melt produced in the experimental studies of Charlier and Grove (2012) to natural rhyolitic compositions. However, immiscible compositions are restricted to $\mathrm{FeO}$-rich and $\mathrm{Al}_{2} \mathrm{O}_{3}$-poor compositions. These two oxides are good indicators of the conditions during differentiation and the influence of water content and crystallization pressure influences the change in these two components during fractional crystallization. As both water content and crystallization pressure increase, the stability field of plagioclase is reduced while pyroxene and olivine stabilities are promoted (Grove and Baker, 1984; Sisson and Grove, 1993; Villiger et al., 2007; Botcharnikov et al., 2008), serving to increase $\mathrm{Al}_{2} \mathrm{O}_{3}$ and decrease $\mathrm{FeO}$. In contrast, anhydrous, low-pressure differentiation is dominated by plagioclase crystallization with minor olivine and clinopyroxene, producing Fe-rich and Al-poor rhyolites; so it promotes the development of immiscibility (Charlier and Grove, 2012).

Comparison with the composition of rhyolitic melts produced by hydrous partial melting of oceanic cumulate gabbros (Koepke et al., 2004; France et al., 2010) and during hydrous crystallization experiments of tholeiitic basalts (Dixon-Spulber and Rutherford, 1983; Berndt et al., 2005) further reinforces the potential role of immiscibility in producing silica melts in tholeiitic provinces (Fig. 9). Hydrous partial melting produces melt with high $\mathrm{Al}_{2} \mathrm{O}_{3}$ (17-22.5 wt.\%), very low $\mathrm{Na}_{2} \mathrm{O}+\mathrm{K}_{2} \mathrm{O}-\mathrm{CaO}$ and low $\mathrm{Fe}$ number (Koepke et al., 2004; France et al., 2010). The compositional range does not overlap with natural compositions. Residual melts produced during hydrous crystallization of basalts at 1-2 kbar cover the $\mathrm{Al}_{2} \mathrm{O}_{3}$-rich side of natural compositions, even if $\mathrm{Na}_{2} \mathrm{O}+\mathrm{K}_{2} \mathrm{O}-\mathrm{CaO}$ is still too low.

\section{STEALTHY DEVELOPMENT OF IMMISCIBILITY}

In a crustal magma chamber, the dense Fe-enriched liquid is not eruptable. This explains why no trace of immiscible ferrobasaltic melt is found in volcanic environments (Fig. 2), although small amounts of iron-rich globules are found in the late-crystallizing mesostasis of erupted basalts (Fig. 3; Philpotts, 1982). Moreover, phases crystallized from both the Fe-rich and Si-rich liquids are the same, with the same compositions. The existence of two immiscible liquids would thus be recorded in the cumulate assemblage by variations of modal proportions, basically indistinguishable compared to crystal settling and sorting or any process that produces igneous layering. Oxide-rich ferrogabbros are the potential cumulates of the Fe-rich liquid. They have been recognized in the lower oceanic crust and in some layered intrusions where immiscibility is documented. In some situations, the two immiscible melts might also not segregate at all and again would produce the same crystallizing phases as the homogeneous melt, in the same proportions. 
Silica-rich late-stage liquid produced by immiscibility would not develop any particular chemical signature compared to continuous fractional crystallization. One can expect some elements such as $\mathrm{Zr}$, U and REE to partition into the iron-rich melt (Watson, 1976; Veksler et al., 2006). However, because immiscibility is reached during silica enrichment, the amount of iron-rich melt produced is relatively small. Its segregation would be equivalent to phase separation produced by crystallization of the equilibrium mineral assemblage, i.e. plagioclase, pyroxenes \pm olivine, Fe-Ti oxides and apatite. Moreover, the two liquids continue to exchange as they crystallize, potentially leave the two-liquid field and continue to evolve by fractionation as a single melt phase.

\section{CONCLUSIONS}

Silicate liquid immiscibility along the tholeiitic liquid line of descent has rarely been invoked to explain largescale differentiation processes from basalt to rhyolite. In this contribution, we have presented various records of unmixing in both volcanic and plutonic environments. Experimental data defining compositional criteria for immiscibility also show that natural trends for major tholeiitic provinces can intersect a two-liquid field. The main implication of immiscibility is the absence of intermediate liquid compositions, a classical feature of tholeiitic trends. Immiscibility does produce silica-rich melts with compositional characteristics similar to natural rhyolites and plagiogranites. The stealthy development of immiscibility and the similarity of phases crystallized from the equilibrium Fe-rich and Si-rich melts complicate the identification of this mechanism. Moreover, the composition of evolved differentiates produced is not supposed to be different to those formed by continuous fractional crystallization. In spite of attempts to rule out liquid immiscibility as a viable process in magmatic differentiation, the evidence provided in this paper supports it operation under low-pressure, anhydrous conditions and shows that compositional and mineralogical evidence, though often cryptic, also support its existence as a potential large-scale magmatic process.

\section{ACKNOWLEDGMENTS}

B.C. acknowledges support by a Marie Curie International Outgoing Fellowship within the 7th European Community Framework Programme. O.N. was supported by a Newton Trust from Trinity College, University of Cambridge. The authors also acknowledge M. Holness, M. Carpenter and D. Pemberton for giving access to the Harker collection at the University of Cambridge. We acknowledge Jean-Clair Duchesne and Ilya Veksler for their comments. This paper has been reviewed by Vadim Kamenetsky and an anonymous reviewer.

\section{APPENDIX A. SUPPLEMENTARY DATA}

Supplementary data associated with this article can be found, in the online version, at http://dx.doi.org/10.1016/ j.gca.2013.03.017.

\section{REFERENCES}

Armstrong J. T. (1995) Citzaf - a package of correction programs for the quantitative electron microbeam X-ray analysis of thick polished materials, thin-films, and particles. Microbeam. Anal. 4, 177-200.

Beard J. S. and Lofgren G. E. (1991) Dehydration melting and water-saturated melting of basaltic and andesitic greenstones and amphibolites at 1,3 , and $6.9 \mathrm{~kb} . J$. Petrol. 32, 365-401.

Berndt J., Koepke J. and Holtz F. (2005) An experimental investigation of the influence of water and oxygen fugacity on differentiation of MORB at $200 \mathrm{MPa}$. J. Petrol. 46, 135-167.

Biggar G. M. (1979) Immiscibility in tholeiites. Mineral. Mag. 43, 543-544.

Bonin B. (2007) A-type granites and related rocks: evolution of a concept, problems and prospects. Lithos 97, 1-29.

Botcharnikov R. E., Almeev R. R., Koepke J. and Holtz F. (2008) Phase relations and liquid lines of descent in hydrous ferrobasalt - implications for the Skaergaard intrusion and Columbia River flood basalts. J. Petrol. 49, 1687-1727.

Bowen N. L. (1928) The Evolution of the Igneous Rocks. Princeton University Press, Princeton, NJ, 334 p.

Brooks C. K. and Nielsen T. F. D. (1978) Early stages in the differentiation of the Skaergaard magma as revealed by a closely related suite of dike rocks. Lithos 11, 1-14.

Brophy J. G. (1991) Composition gaps, critical crystallinity, and fractional crystallization in orogenic (calc-alkaline) magmatic systems. Contrib. Mineral. Petrol. 109, 173-182.

Byerly G. (1980) The nature of differentiation trends in some volcanic rocks from the Galapagos spreading center. $J$. Geophys. Res. 85, 3797-3810.

Byerly G. R., Melson W. G. and Vogt P. R. (1976) Rhyodacites, andesites, ferro-basalts and ocean tholeiites from the galapagos spreading center. Earth Planet. Sci. Lett. 30, 215-221.

Carmichael I. S. E. (1964) The petrology of Thingmuli, a tertiary volcano in eastern Iceland. J. Petrol. 5, 435-460.

Charlier B. and Grove T. L. (2012) Experiments on liquid immiscibility along tholeiitic liquid lines of descent. Contrib. Mineral. Petrol. 164, 27-44.

Charlier B., Namur O., Toplis M. J., Schiano P., Cluzel N., Higgins M. D. and Vander Auwera J. (2011) Large-scale silicate liquid immiscibility during differentiation of tholeiitic basalt to granite and the origin of the Daly gap. Geology 39, 907-910.

Chayes F. (1963) Relative abundance of intermediate members of the oceanic basalt-trachyte association. J. Geophys. Res. 68, $1519-1534$.

Coleman R. G. and Peterman Z. E. (1975) Oceanic plagiogranite. J. Geophys. Res. 80, 1099-1108.

Daly R. A. (1914) Igneous Rocks and their Origin. McGraw-Hill, New York, $563 \mathrm{p}$.

De A. (1974) Silicate liquid immiscibility in the Deccan traps and its petrogenetic significance. Geol. Soc. Am. Bull. 85, 471-474.

Dick, H.J.B., Meyer, P.S., Bloomer, S., Kirby, S., Stakes, D. and Mawer, C., 1991. Lithostratigraphic evolution of an in-situ section of oceanic layer 3. In Proceedings of the Ocean Drilling Program, Scientific Results 118 (eds. R. Von Herzen, P.T. Robinson et al.). College Station, TX. pp. 439-538.

Dick H. J. B. et al. (2000) A long in situ section of the lower ocean crust: results of ODP Leg 176 drilling at the Southwest Indian Ridge. Earth Planet. Sci. Lett. 179, 31-51.

Dixon S. and Rutherford M. J. (1979) Plagiogranites as late-stage immiscible liquids in ophiolite and mid-ocean ridge suites: an experimental study. Earth Planet. Sci. Lett. 45, 45-60. 
Dixon-Spulber S. and Rutherford M. J. (1983) The origin of rhyolite and plagiogranite in oceanic crust: an experimental study. J. Petrol. 24, 1-25.

Duchesne J. C., Shumlyanskyy L. and Charlier B. (2006) The Fedorivka layered intrusion (Korosten Pluton, Ukraine): an example of highly differentiated ferrobasaltic evolution. Lithos 89, 353-376.

Dufek J. and Bachmann O. (2010) Quantum magmatism: magmatic compositional gaps generated by melt-crystal dynamics. Geology 38, 687-690.

Floyd P. A., Yaliniz M. K. and Goncuoglu M. C. (1998) Geochemistry and petrogenesis of intrusive and extrusive ophiolitic plagiogranites, Central Anatolian Crystalline Complex, Turkey. Lithos 42, 225-241.

Fornari D. J., Perfit M. R., Malahoff A. and Embley R. (1983) Geochemical studies of abyssal lavas recovered by DSRV Alvin from eastern Galapagos rift, Inca transform, and Ecuador Rift 1. Major element variations in natural glasses and spacial distribution of lavas. J. Geophys. Res. 88, 10519-10529.

France L., Koepke J., Ildefonse B., Cichy S. and Deschamps F. (2010) Hydrous partial melting in the sheeted dike complex at fast spreading ridges: experimental and natural observations. Contrib. Mineral. Petrol. 160, 683-704.

Frost C. D. and Frost B. R. (1997) Reduced rapakivi-type granites: the tholeiite connection. Geology 25, 647-650.

Frost B. R., Barnes C. G., Collins W. J., Arculus R. J., Ellis D. J. and Frost C. D. (2001) A geochemical classification for granitic rocks. J. Petrol. 42, 2033-2048.

Geist D., Howard K. A. and Larson P. (1995) The generation of oceanic rhyolites by crystal fractionation - the basalt-rhyolite association at Volcan-Alcedo, Galapagos-Archipelago. J. Petrol. 36, 965-982.

Geist D. J., Fornari D. J., Kurz M. D., Harpp K. S., Adam Soule S., Perfit M. R. and Koleszar A. M. (2006) Submarine Fernandina: magmatism at the leading edge of the Galápagos hot spot. Geochem. Geophys. Geosyst. 7, Q12007.

Greenough J. D. and Dostal J. (1992) Layered rhyolite bands in a thick North Mountain basalt flow - the products of silicate liquid immiscibility. Mineral. Mag. 56, 309-318.

Grove T. L. and Baker M. B. (1984) Phase equilibrium controls on the tholeiitic versus calc-alkaline differentiation trends. $J$. Geophys. Res. 89, 3253-3274.

Grove T. L. and Donnelly-Nolan J. M. (1986) The evolution of young silicic lavas at Medicine Lake Volcano, California: implications for the origin of compositional gaps in calcalkaline series lavas. Contrib. Mineral. Petrol. 92, 281-302.

Grove, T.L., Kinzler, R.J. and Bryan, W.B., 1992. Fractionation of midocean ridge basalt (MORB). In Mantle Flow and Melt Generation at Mid-Ocean Ridges (eds. J.P. Morgan, D.K. Blackman, J.M. Sinton). Geophysical Monograph Series. Amer. Geophysical Union, Washington, pp. 281-310.

Gunnarsson B., Marsh B. D. and Taylor H. P. (1998) Generation of Icelandic rhyolites: silicic lavas from the Torfajökull central volcano. J. Volcanol. Geoth. Res. 83, 1-45.

Holness M. B., Stripp G., Humphreys M. C. S., Veksler I. V., Nielsen T. F. D. and Tegner C. (2011) Silicate liquid immiscibility within the crystal mush: late-stage magmatic microstructures in the Skaergaard intrusion, East Greenland. $J$. Petrol. 52, 175-222.

Hooper P. R. (2000) Chemical discrimination of Columbia River basalt flows. Geochem. Geophys. Geosyst. 1, 1024.

Hoover J. D. (1989) The chilled marginal gabbro and other contact rocks of the Skaergaard intrusion. J. Petrol. 30, 441-476.

Humphreys M. C. S. (2011) Silicate liquid immiscibility within the crystal mush: evidence from $\mathrm{Ti}$ in plagioclase from the Skaergaard intrusion. J. Petrol. 52, 147-174.
Humphris S. E. and Thompson G. (1982) A geochemical study of rocks from the Walvis Ridge, South Atlantic. Chem. Geol. 36, 253-274.

Hunter R. H. and Sparks R. S. J. (1987) The differentiation of the Skaergaard intrusion. Contrib. Mineral. Petrol. 95, 451-461.

Irvine T. N. (1976) Metastable liquid immiscibility and $\mathrm{MgO}-\mathrm{FeO}$ $\mathrm{SiO}_{2}$ fractionation patterns in the system $\mathrm{Mg}_{2} \mathrm{SiO}_{4}-\mathrm{Fe}_{2} \mathrm{SiO}_{4}$ $\mathrm{CaAl}_{2} \mathrm{Si}_{2} \mathrm{O}_{8}-\mathrm{KAlSi}_{3} \mathrm{O}_{8}-\mathrm{SiO}_{2}$. Carnegie Institution of Washington Yearbook 75, 597-611.

Jakobsen J. K., Veksler I. V., Tegner C. and Brooks C. K. (2005) Immiscible iron- and silica-rich melts in basalt petrogenesis documented in the Skaergaard intrusion. Geology 33, $885-888$.

Jakobsen J., Tegner C., Brooks C., Kent A., Lesher C., Nielsen T. and Wiedenbeck M. (2010) Parental magma of the Skaergaard intrusion: constraints from melt inclusions in primitive troctolite blocks and FG-1 dykes. Contrib. Mineral. Petrol. 159, 6179.

Jakobsen J. K., Veksler I. V., Tegner C. and Brooks C. K. (2011) Crystallization of the Skaergaard intrusion from an emulsion of immiscible iron- and silica-rich liquids: evidence from melt inclusions in plagioclase. J. Petrol. 52, 345-373.

Juster T. C., Grove T. L. and Perfit M. R. (1989) Experimental constraints on the generation of FeTi basalts, andesites, and rhyodacites at the Galapagos spreading center, $85 \mathrm{~W}$ and $95 \mathrm{~W}$. J. Geophys. Res. 94, 9251-9274.

Kerr A. C., Kent R. W., Thomson B. A., Seedhouse J. K. and Donaldson C. H. (1999) Geochemical evolution of the Tertiary Mull volcano, western Scotland. J. Petrol. 40, 873-908.

Koepke J., Feig S., Snow J. and Freise M. (2004) Petrogenesis of oceanic plagiogranites by partial melting of gabbros: an experimental study. Contrib. Mineral. Petrol. 146, 414-432.

Koepke J., Berndt J., Feig S. T. and Holtz F. (2007) The formation of $\mathrm{SiO}_{2}$-rich melts within the deep oceanic crust by hydrous partial melting of gabbros. Contrib. Mineral. Petrol. 153, 67-84.

Kontak D. J., De Wolfe De Young M. Y. and Dostal J. (2002) Late-stage crystallization history of the Jurassic North Mountain Basalt, Nova Scotia, Canada. I. Textural and chemical evidence for pervasive development of silicate-liquid immiscibility. Can. Mineral. 40, 1287-1311.

le Roex A. P., Dick H. J. B., Reid A. M. and Erlank A. J. (1982) Ferrobasalts from the Spiess ridge segment of the Southwest Indian ridge. Earth Planet. Sci. Lett. 60, 437-451.

Luais B. (1987) Immiscibilité entre liquides silicatés dans les mésostases et les inclusions vitreuses des andésites basiques de Santorin (Arc Egéen). Bull. Minéral. 110, 93-109.

Ludden J. N., Thompson G., Bryan W. B. and Frey F. A. (1980) The origin of lavas from the Ninetyeast ridge, eastern Indian ocean: an evaluation of fractional crystallization models. $J$. Geophys. Res. 85, 4405-4420.

Mahoney J. J., Jones W. B., Frey F. A., Salters V. J. M., Pyle D. G. and Davies H. L. (1995) Geochemical characteristics of lavas from Broken Ridge, the Naturaliste Plateau and southernmost Kerguelen Plateau: Cretaceous plateau volcanism in the southeast Indian Ocean. Chem. Geol. 120, 315-345.

Mahoney J. J., Saunders A. D., Storey M. and Randriamanantenasoa A. (2008) Geochemistry of the volcan de l'Androy basaltrhyolite complex, Madagascar Cretaceous igneous province. $J$. Petrol. 49, 1069-1096.

Marsh B. D. (1981) On the crystallinity, probability of occurrence, and rheology of lava and magma. Contrib. Mineral. Petrol. 78, 85-98.

Martin B. and Kushiro I. (1991) Immiscibility synthesis as an indication of cooling rates of basalts. J. Volcanol. Geoth. Res. 45, 289-310. 
Mathison C. I. and Hamlyn P. R. (1987) The McIntosh layered troctolite-olivine gabbro intrusion, East Kimberley, Western Australia. J. Petrol. 28, 211-234.

McBirney A. R. (1975) Differentiation of the Skaergaard intrusion. Nature 253, 691-694.

McBirney A. R. (1989) The Skaergaard layered series: I. Structure and average compositions. J. Petrol. 30, 363-397.

McBirney A. R. and Naslund H. R. (1990) The differentiation of the Skaergaard intrusion, a discussion of Hunter and Sparks. Contrib. Mineral. Petrol. 104, 235-240, Contrib. Mineral. Petrol. 95:451-461.

McBirney A. R. and Williams H. (1969) Geology and petrology of the Galápagos Islands. Geol. Soc. Am. Mem. 118, 1-197.

Melson W. G. and O'Hearn T. (1986) Zero-age variations in the composition of abyssal volcanic rocks along the axial zone of the mid-Atlantic Ridge. In Decade of North American Geology series - The North Atlantic Sea Floor (eds. B. Tucholke and P. Vogt). Geological Society of America, pp. 117-136.

Meschede M. (1986) A method of discriminating between different types of mid-ocean ridge basalts and continental tholeiites with the $\mathrm{Nb}-\mathrm{Zr}-\mathrm{Y}$ diagram. Chem. Geol. 56, 207-218.

Miller J. D. and Ripley E. M. (1996) Layered intrusions of the Duluth Complex, USA. In Layered Intrusions (ed. R. G. Cawthorn). Elsevier, Amsterdam, pp. 257-301.

Montanini A., Travaglioli M., Serri G., Dostal J. and Ricci C. (2006) Petrology of gabbroic to plagiogranitic rocks from southern Tuscany (Italy): evidence for magmatic differentiation in an ophiolitic sequence. Ofioliti 31, 55-69.

Mullen E. D. (1983) $\mathrm{MnO} / \mathrm{TiO}_{2} / \mathrm{P}_{2} \mathrm{O}_{5}$ : a minor element discriminant for basaltic rocks of oceanic environments and its implications for petrogenesis. Earth Planet. Sci. Lett. 62, 53-62.

Mungall J. and Martin R. (1995) Petrogenesis of basalt-comendite and basalt-pantellerite suites, Terceira, Azores, and some implications for the origin of ocean-island rhyolites. Contrib. Mineral. Petrol. 119, 43-55.

Mysen B. O. (1983) The structure of silicate melts. Annu. Rev. Earth Planet. Sci. 11, 75-97.

Namur O., Charlier B., Toplis M. J., Higgins M. D., Liégeois J.-P. and Vander Auwera J. (2010) Crystallization sequence and magma chamber processes in the ferrobasaltic Sept Iles layered intrusion, Canada. J. Petrol. 51, 1203-1236.

Namur O., Charlier B., Toplis M. J., Higgins M. D., Hounsell V., Liégeois J.-P. and Vander Auwera J. (2011) Differentiation of tholeiitic basalt to A-type granite in the Sept Iles layered intrusion, Canada. J. Petrol. 52, 487-539.

Namur O., Charlier B. and Holness M. (2012) Dual origin of FeTi-P gabbros by immiscibility and fractional crystallization of evolved tholeiitic basalts in the Sept Iles layered intrusion. Lithos 154, 100-114.

Natland J. H. and Dick H. J. B. (2001) Formation of the lower ocean crust and the crystallization of gabbroic cumulates at a very slowly spreading ridge. J. Volcanol. Geoth. Res. 110, 191233.

Natland, J.H., Meyer, P.S., Dick, H.J.B. and Bloomer, S.H. (1991). Magmatic oxides and sulfides in gabbroic rocks from Hole 735B and the later development of the liquid line of descent. In Proceedings of the Ocean Drilling Program, Scientific Results 118 (eds. R. Von Herzen, P.T. Robinson et al.). College Station, TX, pp. 75-112.

Niu, Y., Gilmore, T., Mackie, S., Greig, A. and Bach, W. (2002). Mineral chemistry, whole-rock compositions, and petrogenesis of Leg 176 gabbros: Data and discussion. In Proceedings of the Ocean Drilling Program, Scientific Results 176 (eds. J.H. Natland, H.J.B. Dick et al.). College Station, TX, pp. 1-60.
Ozawa, K., Meyer, P.S. and Bloomer, S.H. (1991). Mineralogy and textures of iron-titanium oxide gabbros and associated olivine gabbros from Hole 735B. In Proceedings of the Ocean Drilling Program, Scientific Results 118 (eds. R. Von Herzen, P.T. Robinson et al.). College Station, TX, pp. 41-73.

Pearce T. H., Gorman B. E. and Birkett T. C. (1975) The $\mathrm{TiO}_{2}$ $\mathrm{K}_{2} \mathrm{O}-\mathrm{P}_{2} \mathrm{O}_{5}$ diagram: a method of discriminating between oceanic and non-oceanic basalts. Earth Planet. Sci. Lett. 24, 419-426.

Peate D. W., Hawkesworth C. J. and Mantovani M. S. M. (1992) Chemical stratigraphy of the Paraná lavas (South America): classification of magma types and their spatial distribution. Bull. Volcanol. 55, 119-139.

Peccerillo A., Barberio M. R., Yirgu G., Ayalew D., Barbieri M. and $\mathrm{Wu} \mathrm{T}$. W. (2003) Relationships between mafic and peralkaline silicic magmatism in continental rift settings: a petrological, geochemical and isotopic study of the Gedemsa volcano, central Ethiopian rift. J. Petrol. 44, 2003-2032.

Philpotts A. R. (1979) Silicate liquid immiscibility in tholeiitic basalts. J. Petrol. 20, 99-118.

Philpotts A. R. (1981) A model for the generation of massif-type anorthosites. Can. Mineral. 19, 233-253.

Philpotts A. R. (1982) Compositions of immiscible liquids in volcanic rocks. Contrib. Mineral. Petrol. 80, 201-218.

Philpotts A. R. and Doyle C. D. (1983) Effect of magma oxidation state on the extent of silicate liquid immiscibility in a tholeiitic basalt. Am. J. Sci. 283, 967-986.

Pik R., Deniel C., Coulon C., Yirgu G., Hofmann C. and Ayalew D. (1998) The northwestern Ethiopian Plateau flood basalts: classification and spatial distribution of magma types. $J$. Volcanol. Geoth. Res. 81, 91-111.

Putnis A. and McConnell J. D. C. (1980) Principles of Mineral Behaviour. Elsevier, New York, 258 pp.

Ripley E. M., Severson M. J. and Hauck S. A. (1998) Evidence for sulfide and $\mathrm{Fe}$-Ti-P-rich liquid immiscibility in the Duluth Complex, Minnesota. Econ. Geol. 93, 1052-1062.

Roedder E. W. (1951) Low temperature liquid immiscibility field in the system $\mathrm{K}_{2} \mathrm{O}-\mathrm{FeO}-\mathrm{Al}_{2} \mathrm{O}_{3}-\mathrm{SiO}_{2}$. Am. Mineral. 36, 282-286.

Roedder E. and Weiblen P. W. (1970) Lunar petrology of silicate melt inclusions, Apollo 11 rocks. Geochim. Cosmochim. Acta 1(Suppl. 1), 507-528.

Roedder E. and Weiblen P. W. (1971) Petrology of silicate melt inclusions, Apollo 11 and Apollo 12 and terrestrial equivalents. Geochim. Cosmochim. Acta 1(Suppl. 2), 507-528.

Sano T., Fujii T., Deshmukh S. S., Fukuoka T. and Aramaki S. (2001) Differentiation processes of Deccan trap basalts: contribution from geochemistry and experimental petrology. $J$. Petrol. 42, 2175-2195.

Sato H. (1978) Segregation vesicles and immiscible liquid droplets in ocean-floor basalt of Hole 396B, IPOD/DSDP Leg 46. In Initial Reports of the Deep Sea Drilling Project, vol. 46 (eds. L. Bimitriev and J. Heirtzler, et al.). U.S. Government Printing Office, Washington, pp. 283-291.

Sisson T. W. and Grove T. L. (1993) Experimental investigations of the role of $\mathrm{H}_{2} \mathrm{O}$ in calc-alkaline differentiation and subduction zone magmatism. Contrib. Mineral. Petrol. 113, 143-166.

Smith M. C., Perfit M. R. and Jonasson I. R. (1994) Petrology and geochemistry of basalts from the southern Juan de Fuca Ridge: controls on the spatial and temporal evolution of mid-ocean ridge basalt. J. Geophys. Res. 99, 4787-4812.

Tegner C. (1997) Iron in plagioclase as a monitor of the differentiation of the Skaergaard intrusion. Contrib. Mineral. Petrol. 128, 45-51.

Tegner C. and Cawthorn R. (2010) Iron in plagioclase in the Bushveld and Skaergaard intrusions: implications for iron 
contents in evolving basic magmas. Contrib. Mineral. Petrol. 159, 719-730.

Tegner C., Cawthorn R. G. and Kruger F. J. (2006) Cyclicity in the Main and Upper Zones of the Bushveld complex, South Africa: crystallization from a zoned magma sheet. J. Petrol. 47, 22572279.

Thompson R. N. (1972) Evidence for a chemical discontinuity near the basalt-andesite transition in many anorogenic volcanic suites. Nature 236, 106-110.

Thy P., Lesher C. E., Nielsen T. F. D. and Brooks C. K. (2006) Experimental constraints on the Skaergaard liquid line of descent. Lithos 92, 154-180.

Thy P., Lesher C. and Tegner C. (2009) The Skaergaard liquid line of descent revisited. Contrib. Mineral. Petrol. 157, 735-747.

Toplis M. J. and Carroll M. R. (1995) An experimental study of the influence of oxygen fugacity on $\mathrm{Fe}-\mathrm{Ti}$ oxide stability, phase relations, and mineral-melt equilibria in ferro-basaltic systems. J. Petrol. 36, 1137-1170.

Toplis M. J. and Carroll M. R. (1996) Differentiation of ferrobasaltic magmas under conditions closed and open to oxygen: implications for the Skaergaard intrusion and other natural systems. J. Petrol. 37, 837-858.

Tormey D. R., Grove T. L. and Bryan W. B. (1987) Experimental petrology of normal MORB near the Kane Fracture Zone: 2225 N, mid-Atlantic ridge. Contrib. Mineral. Petrol. 96, 121-139.

Turner S. and Rushmer T. (2009) Similarities between mantlederived A-type granites and voluminous rhyolites in continental flood basalt provinces. Earth Environ. Sci. Trans. Royal Soc. Edinburgh 100, 51-60.

Vander Auwera J., Longhi J. and Duchesne J. C. (1998) A liquid line of descent of the jotunite (hypersthene monzodiorite) suite. J. Petrol. 39, 439-468.

VanTongeren J. A. and Mathez E. A. (2012) Large-scale liquid immiscibility at the top of the Bushveld Complex, South Africa. Geology 40, 491-494.

VanTongeren J. A., Mathez E. A. and Kelemen P. B. (2010) A felsic end to Bushveld differentiation. J. Petrol. 51, 1891-1912.

Veksler I., Dorfman A., Danyushevsky L., Jakobsen J. and Dingwell D. B. (2006) Immiscible silicate liquid partition coefficients: implications for crystal-melt element partitioning and basalt petrogenesis. Contrib. Mineral. Petrol. 152, 685-702.

Veksler I. V., Dorfman A. M., Borisov A. A., Wirth R. and Dingwell D. B. (2007) Liquid immiscibility and the evolution of basaltic magma. J. Petrol. 48, 2187-2210.
Veksler I. V., Dorfman A. M., Borisov A. A., Wirth R. and Dingwell D. B. (2008) Liquid immiscibility and evolution of basaltic magma: Reply to S.A. Morse, A.R. McBirney and A.R. Philpotts. J. Petrol. 49, 2177-2186.

Veksler I. V., Kahn J., Franz G. and Dingwell D. B. (2010) Interfacial tension between immiscible liquids in the system $\mathrm{K}_{2} \mathrm{O}-\mathrm{FeO}-\mathrm{Fe}_{2} \mathrm{O}_{3}-\mathrm{Al}_{2} \mathrm{O}_{3}-\mathrm{SiO}_{2}$ and implications for the kinetics of silicate melt unmixing. Am. Mineral. 95, 1679-1685.

Villiger S., Ulmer P. and Müntener O. (2007) Equilibrium and fractional crystallization experiments at $0.7 \mathrm{GPa}$ : the effect of pressure on phase relations and liquid compositions of tholeitic magmas. J. Petrol. 48, 159-184.

Wager L. R. and Brown G. M. (1968) Layered Igneous Rocks. Oliver \& Boyd, Edinburgh, 588 p.

Walker D., Shibata T. and DeLong S. (1979) Abyssal tholeiites from the Oceanographer Fracture Zone. Contrib. Mineral. Petrol. 70, 111-125.

Walsh J. N., Beckinsale R. D., Skelhorn R. R. and Thorpe R. S. (1979) Geochemistry and petrogenesis of tertiary granitic rocks from the Island of Mull, Northwest Scotland. Contrib. Mineral. Petrol. 71, 99-116.

Watson E. B. (1976) Two-liquid partition coefficients: experimental data and geochemical implications. Contrib. Mineral. Petrol. 56, 119-134.

Wiebe R. A. (1979) Fractionation and liquid immiscibility in an anorthositic pluton of the Nain complex, Labrador. J. Petrol. 20, 239-269.

Wiebe R. A. and Snyder D. (1993) Slow, dense replenishments of a basic magma chamber: the layered series of the Newark Island layered intrusion, Nain, Labrador. Contrib. Mineral. Petrol. 113, 59-72.

Wilson J. R. and Overgaard G. (2005) Relationship between the layered series and the overlying evolved rocks in the BjerkreimSokndal Intrusion, southern Norway. Lithos 83, 277-298.

Wilson J. R., Robins B., Nielsen F. M., Duchesne J. C. and Vander Auwera J. (1996) The Bjerkreim-Sokndal layered intrusion, Southwest Norway. In Layered Intrusions (ed. R. G. Cawthorn). Elsevier, Amsterdam, pp. 231-255.

Xu Y., Chung S.-L., Jahn B.-m. and Wu G. (2001) Petrologic and geochemical constraints on the petrogenesis of Permian-Triassic Emeishan flood basalts in southwestern China. Lithos 58, 145168. 